THURSDAY, JULY 30, IQ̣i4.

\section{MAMMALIAN EVOLUTION.}

A History of Land Mammals in the Western Hemisphere. By Prof. W. B. Scott. Pp. xiv +693. (New York: The Macmillan Company; London: Macmillan and Co., Ltd., I913.) Price 2 is. net.

THIS important work is, perhaps, the most successful attempt that has yet been made to bring within the reach of the lay reader a general account of the past history of the mammalia, a history for the reconstruction of which a vast amount of material is now available. It may be regretted that the author has found it necessary to confine his work to the mammals of the Western Hemisphere, but since the successive faunas inhabiting that region, particularly the northern half, are far better known than those of the Old World, none of the main lines along which evolution has proceeded within the group is left without adequate illustration. The much greater degree of completeness of our knowledge of the mammals of the New World is not merely due to the occurrence there of a more nearly continuous series of mammal-bearing tertiary deposits, but also to the systematic collecting that has been carried out, both in the north and south, by expeditions organised by the museums and universities. Prof. Scott has himself led such expeditions on several occasions.

The plan of the work is excellent, especially from the point of view of the general reader. The earlier chapters give a simple summary of the methods of investigation, both from a geological and palæontological point of view. A valuable chapter is added giving a brief, but clear, account of the mammalian skeleton and dentition; this with the accompanying figures should render the descriptions given in the later part of the work easily understood. A chapter on the living mammals of America is followed by a history of the succession of mammalian faunas back to the earliest Eocene, the pre-Tertiary forms being omitted. So far the volume may be regarded as an introduction to mammalian palæontology generally. In the succeeding part of the work the evolution of each group is traced in detail from its earliest appearance onwards, and it is this section which will be a revelation to those who are unacquainted with the enormous amount of material for the history of the phylum that has accumulated during the last quarter of a century. All zoologists who, from various points of view, are No. 2335, vol. 93] dealing with the question of the manner in which evolution has taken place, should read this sum:mary of results, in which much light is thrown on such points as the occurrence of parallel and convergent evolution and on the origin of polyphyletic groups.

It is often forgotten that in palæontology we are dealing with what actually has happened, and nowhere is this better known than in the case of the mammalia. Prof. Scott himself seems to be somewhat unduly pessimistic as to the present state of palæontology, comparing it with the condition of philology in the time of Voltaire, whose famous remark: “L'étymologie est une science ou les voyelles ne font rien et les consonnes fort peu de chose," he quotes. The fact that it has been possible to write this book seems to be sufficient proof that matters are not so bad as he appears to believe.

A large number of excellent illustrations are given, many being restorations of extinct mammals, a considerable number now appearing for the first time. A useful glossary and a very complete index are appended. C. W. A.

\section{THE PRODUCTION AND UTILISATION OF CROPS.}

(I) The Manuring of Market Garden Crops. By Dr. Bernard Dyer and F. W. E. Shrivell. New Edition. Revised and brought up to date. Pp. I49. (London: Vinton and Co., Ltd. I9I3.) Price Is.

(2) The Chemistry of Cattle Feeding and Dairying. By J. Alan Murray. Pp. xii +343 . (London: Longmans, Green and Co., r9r4.) Price $6 s$. net.

(3) Garden Farming. By L. C. Corbett. Pp. $\mathrm{x}+$ 473. (Boston and London: Ginn and Co., n.d.) Price $8 s .6 d$.

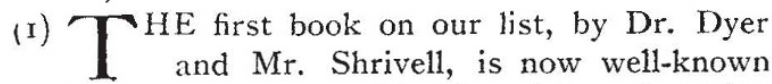
to all who are concerned in the raising of market garden crops. It gives the results of a series of trials at Golden Green, Hadlow, Tonbridge, which were begun in 1894 and have been systematically carried out since, so that they are now in their twentieth year.

When the experiments began little was known as to the effect of the various artificial manures on market garden crops. Many trials had been made with ordinary farm crops, but not much had been done with fruit and practically nothing with ordinary vegetables. The market gardener still used large quantities of stable manure and looked with more or less suspicion on all the purchased 